\title{
The Impact of Information Technology on Developing Creative Writing Skills and Academic Self-Efficacy for Undergraduate Students
}

\author{
Turki Rabah Al Mukhallafi ${ }^{1}$ \\ ${ }^{1}$ English Language Skills Department, Northern Border University, Rafha, Kingdom of Saudi Arabia \\ Correspondence: Turki Rabah Al Mukhallafi, English Language Skills Department, Northern Border University, \\ Rafha, Kingdom of Saudi Arabia. E-mail: hoppy4u@hotmail.com
}

Received: September 3, $2021 \quad$ Accepted: October 20, $2021 \quad$ Online Published: November 5, 2021

doi:10.5539/ijel.v12n1p12 URL: https://doi.org/10.5539/ijel.v12n1p12

\begin{abstract}
The current study aimed to construct a strategy based on information technology for teaching English (English Course 102), and assess its impact on developing creative writing skills and academic self-efficacy for university students. A test of creative writing skills (fluency, flexibility, and originality) was also prepared, including (9) graded open-ended essay questions in creative writing skills, also the preparation of the academic self-efficacy scale, including (25) items in the following dimensions: the student's self-motivation to learn; the student's confidence in the ability to achieve; perseverance and continuity in learning; self-regulation of learning and recall habits. The study based on the experimental method, involving two groups, the experimental and the control group (pre-post). The study sample consisted of (64) second-year university students studying the course (English 102), which aims to develop language proficiency in academic writing skills. The sample was divided into two groups: experimental (32) and control (32). Results indicated that: There are statistically significant differences at level $(\alpha \leq 0.01)$ between the mean scores of the students from the experimental and control groups in the post application for testing creative writing skills and each skill separately in favor of the experimental group, there are statistically significant differences between the mean scores of the experimental group students in the pre and post applications for testing creative writing skills and each skill separately and also of the academic self-efficacy scale and each dimension separately in favor of the experimental group , there are statistically significant differences between the mean scores of the students from the experimental and control groups in the post application of the academic self-efficacy scale and each dimension separately in favor of the experimental group, and there is a positive correlation between scores of the experimental group in favor of the post application of the creative writing test and their scores on the academic self-efficacy scale.
\end{abstract}

Keywords: information technology, English language teaching (ELT), creative writing

\section{Introduction}

Language is considered one of the essential subjects in educational systems, a tool in building a student's personality in a proper, integrated and compatible manner. Language is also a method for thinking, a container of thought, and a means of preserving and transmitting heritage between generations. The processes of teaching and learning English for university students are linked to the development of the student's skills in reading and researching, also in building student abilities in productive writing.

Writing skills are one of the core language building skills. Furthermore, writing skills are one of the most complex language skills, requiring more abilities than other skills of language construction (listening, speaking, and reading). At the university level, writing skills are necessary for academic achievement: summarizing, taking notes, writing articles, reports and scientific research, writing educational and study projects, answering accurately and clearly in tests, including questions of both short and long essay style (Musa, 2016, p. 52).

Creative writing skills are among the objectives of language teaching, to train students to imagine and produce ideas, along with training on linguistic selection, and scrutiny in the choice of words and formulations. It is noted that developing creative writing skills enhances students' levels of language skills as a whole (listening, speaking, reading, and writing) (Al-Zahrani, 2017, p. 163).

Creative writing skills are defined as the student's ability to express feelings, thoughts, beliefs, and fantasies in a 
clear linguistic format, style and meaning, accurate in structure (Nasr, Faraj, \& Suleiman, 2019, p. 114).

The Saudi study (2017, p. 91) showed the importance of developing students' creative writing skills, as they are directly related to language skills and language development, which affect the integrated development of the student's personality.

Creative writing includes a group of skills and processes that must be considered during teaching planning, so they are developed and measured in a continuous manner. Among the most important of these skills and processes are the following (Mahmoud, 2018, p. 240):

- Creative writing skills: These include grammatical skills, proficiency in using punctuation, checking spelling, using a distinguished literary style, organizing content, topic building skills, using linking tools, technical standards for writing, and other skills.

- Creative writing processes: These include mental processes (topic planning, writing planning and subject building planning), and performativity processes related to production and writing. The development of creative writing skills, whether in the mother tongue (Arabic) or the foreign language (English), is one of the skills absent in the field, as many studies have shown, including Hanna (2018, p. 6).

In this context, studies have indicated that creative writing skills are a necessary requirement to improve students' functional writing skills, which depend on the connection with reality and its problems, expression and events, while creative writing skills depend on fertile imagination and thinking, and this is a necessary requirement for improving students' writing production.

Academic self-concept is necessary to improve a student's levels of writing. Besides, students with high academic self-concept are able to actively participate, exert more effort, persevere in educational activities, confront failure practices and educational difficulties (Musa, 2016, p. 53).

Academic self-concept is affected by a group of factors that can be used to predict the academic self-efficacy level of undergraduate students as follows: student's ability to plan his learning, self-control, reduce anxiety, increase attention, motivation, persevere, participate in educational activities, social support, positivity in educational or life situations, flexibility, activity, a high degree of enthusiasm, high intelligence and adaptability in diverse situations (Al-Rasheed, 2019, p. 176).

According to a study by Hassanein (2011, p. 51) academic self-efficacy is directly related to the student's opinion of himself in the academic fields, his criticism about his actual abilities and skills, and his perception about those abilities. (Bandura) According to the premise of social learning theory, the most important features are:

- Students tend to persist in educational tasks in which they feel successful or are able to complete successfully and accurately.

- Academic self-efficacy motivates students towards excitement and challenge in educational situations and tasks, and directs them towards high-level educational activities.

- An active academic self-concept enhances students' self-regulation processes in the mental, behavioral and emotional aspects, making them able to plan goals and persevere in achieving them.

- Academic self-efficacy enhances students in taking responsibility for learning, facing failure and learning difficulties, dealing with them in an objective manner that can be remedied through planning and research processes.

Several studies, including Wai (2012, p. 103) and Mahram (2012), showed the importance of using information technology in teaching and education for its effectiveness in diversifying teaching strategies, addressing multiple styles in teaching and learning, organizing knowledge and presenting it in different ways, and enriching the educational situation to meet student needs, taking into account the differences between students' abilities and previous experiences.

The results of studies by Al-Zayni and Abdel-Aziz (2010, p. 117) and Al-Araimi (2020, p. 331) on the effectiveness of using information technology-based teaching strategies in language learning showed their impact on developing the educational situation, including traditional, virtual and digital educational environments. Such strategies provide students with a variety of tools, experiences and educational resources that help them plan their learning and manage learning as a successful educational project.

Also, information technology strategies integrate the student into an educational situation before the learning event, by participating in planning educational experiences and designing digital content. Language 
communication skills are enhanced through tools, applications of modeling, and simulation, directing students towards self-learning and continuous training in language skills without being restricted to time or spatial learning limitations, while directing students towards self-assessment (Al Mukhallafi, 2019).

\section{Problems and Study Questions}

Several studies, including the Mahmoud study (2018), indicated a decline in students' levels on tests measuring creative writing skills, which appear in indicators that students do not have the skills to produce new ideas and use text editing models. The low levels of students in creative writing skills are attributed to shortcomings in teaching practices and strategies, and the adoption of traditional teaching strategies based on student guidance according to specific written models that do not provide the student with an opportunity for creativity in writing.

Through teaching English courses to university students, whether in the joint program (preparatory year) or during specialized programs or university requirements, low levels in writing skills in general, and low levels in creative writing skills in particular, were found.

Based on the previous discussion, the problem of the current study is determined by the low levels of university students in creative writing skills on the one hand, and the lack of clarity of the academic self-concept on the other hand. This may be attributed to many factors, including the traditional teaching strategies used. In order to solve the described problem, the study attempts to answer this main question: What is the impact of the proposed strategy based on information technology on developing creative writing skills and academic self-efficacy in English for undergraduate students?

From the main question, the following sub-questions are derived:

Question 1: What is the information technology-based strategy for developing creative writing skills and academic self-efficacy in English for university students?

Question 2: What is the impact of the information technology-based strategy on developing creative writing skills in English for university students?

Question 3: What is the impact of the information technology-based strategy on academic self-development in English for university students?

Question 4: What is the type and level of the correlation between students' scores in creative writing skills and their scores on the Academic Self-Efficacy Scale in English language?

\section{Aims of the Study}

The current study aimed to:

1) Build a proposed teaching strategy based on information technology for teaching English and developing creative writing skills for university students.

2) Investigate the impact of the proposed strategy based on information technology for teaching English on developing creative writing skills for university students.

3) Investigate the impact of the proposed strategy based on information technology for teaching English on the development of components of the academic self-concept among university students.

4) Study the type and level of the correlation between students' scores in creative writing skills and their scores on the Academic Self-Efficacy Scale in English.

\section{Importance of the Study}

The theoretical importance of the current study stems from the contemporary local global trends in the development of teaching practices and strategies, besides the transition from traditional teaching to teaching centered on the use of information technology and communication technology tools. It also stems from the fact that writing skills in general, and creative writing skills in particular, are among a student's building language skills. They are also among general objectives of teaching English in the university program, because of their importance to students in writing research and scientific reports, and are among the strengths and distinctions of the university student.

The practical significance of the study is also determined by the following:

(A) It presents to university staff members an information technology-based teaching strategy that explains how to use information technology tools and formulas in a procedural manner in teaching activities and practices.

(B) It is beneficial for university staff members who specialize in English language for developing and measuring students' creative writing skills in educational programs, considering writing skills as part of language 
skills (listening, speaking, reading, and writing), with an understanding of how to develop and measure the components of the academic self-concept and its relationship to developing creative writing skills.

(C) It offers the undergraduate students activities included in the teaching scenarios. These educational activities are based on information technology for the possibility of developing and measuring creative writing skills on their own, or as directed by faculty members.

(D) It provides researchers in the fields of English language teaching and learning a conceptual framework on the development of creative writing skills and the components of the academic self-concept: as well as an opportunity to develop each of them using a proposed teaching strategy based on information technology, while measuring it with appropriate tools.

\section{Limitations of the Study}

\subsection{Objective Limitations}

The current study was limited to creative writing skills in three areas: language skills, production skills, and organizational skills; and in the three components of creativity (fluency, flexibility and originality). In information technology, it is limited to the applied aspects of e-learning and mobile learning that are appropriate for learning English language skills.

\subsection{Human Limitations}

A sample of second-year university students who are studying a course (English 2) at the Faculty of Arts at Northern Border University, Saudi Arabia.

\subsection{Time and Place Limitations}

The tools of the current study (educational tools, including the proposed strategy, and data collection tools, including tests of creative writing skills and the Academic Self-Efficacy Scale) were applied and conducted in the second semester in the academic year 1441/1442 AH, on a sample of students from the Faculty of Arts at Northern Border University.

\section{Hypotheses of the Study}

To answer the questions of the study through extrapolation and analysis of previous studies, five statistical hypotheses were formulated.

\section{Hypothesis 1:}

There are statistically significant differences at level $(\alpha \leq 0.01)$ between the mean scores of students from experimental and control groups in the post application of the creative writing skills test in general, and each skill separately, in favor of the experimental group.

\section{Hypothesis 2:}

There are statistically significant differences at level $(\alpha \leq 0.01)$ between the mean scores of the experimental group of students in the pre and post applications to test creative writing skills in general, and each skill separately, in favor of the experimental group.

\section{Hypothesis 3:}

There are statistically significant differences at level $(\alpha \leq 0.01)$ between the mean scores of students from the experimental and control groups in the post application of the academic self-efficacy scale in general, and each dimension separately, in favor of the experimental group.

\section{Hypothesis 4:}

There are statistically significant differences at level $(\alpha \leq 0.01)$ between the mean scores of the experimental group in the two pre and post applications of the academic self-efficacy scale in general, and each dimension separately, in favor of the experimental group.

\section{Hypothesis 5:}

There is a positive correlation between the scores of the experimental group in favor of the post application of the creative writing test and their scores on the academic self-efficacy scale.

\section{Definition Terms}

\subsection{Creative Writing Skills}

Al-Harbi (2015) defines this as a group of written/shaped symbols produced by the student to explain his 
knowledge, feelings, values and trends, expressed according to the rules of language controls related to clarity, accuracy, speed and beauty, and representing a meaning characterized by fluency, flexibility, and originality. Al-Naimi $(2017$, p. 95) defines it as a set of written linguistic performances acquired through continuous education and training, and student performance is measured according to three components (fluency, flexibility, and originality). Qhouf (2018, p. 178) defines it as a student's ability to express his thoughts and feelings in an accurate and clear manner that affects the recipient, bearing in mind that his linguistic production is characterized by fluency, flexibility, and originality.

\subsection{Operationally}

Creative writing skills is operationally defined in the current study as a group of written linguistic educational practices according to controls related to the components of creativity (fluency, flexibility, and originality). Creative writing skills in the current study are measured through each student's score on the test.

\subsection{Academic Self-Efficacy}

Ghanem (2018, p. 706) defines it as a student's opinion of himself in a specific field, in terms of his abilities for academic achievement, performance of educational tasks, and continuity in performing those duties. Also, Ahmed (2016, p. 92) defines it as the university student's feeling about his academic potential and capabilities, in terms of the level of those abilities and skills.

\subsection{Operationally}

Academic self-efficacy is defined operationally in the current study according to the university student's perception of himself, his abilities, and his belief about his level of English language skills, together with his conviction that he can accomplish tasks, educational activities and achievement tests with a high degree of success. Also, academic self-efficacy in the current study is related to the development of self-motivation to learn English in general, mastery of creative writing skills, confidence in the possibility of successful achievement, perseverance and continuity in learning, and self-regulation of learning and recall.

\subsection{Information Technology}

Al-Araimi (2020, p. 333) defines it as a technology based on electronics that can be used to collect, store, process data information and put it in accessible packages, enabling the student to benefit from it in building knowledge or communication.

\subsection{Operationally}

Information technology is operationally defined in the current study as the sequence of a group of practices and procedures using information technology applications and tools that enhance the student's knowledge and research on a specific idea, with discussion in traditional or virtual sessions between students and a faculty staff member with the aim of developing creative writing skills in English, reflected in achieving self-efficacy.

\section{Study Methods}

\subsection{Method of the Study}

The current study relied on the descriptive analytical approach to describe the variables of the study, and to derive the foundations of the proposed strategy based on information technology for teaching English courses and developing creative writing and academic self-efficacy among university students. The current study depended on the quasi-experimental approach to study the impact of the proposed strategy on developing creative writing and academic self-efficacy.

\subsection{The Study Sample}

The study sample consisted of (64) second-year students from the English department, in two groups, the first an experimental group (32), and the second a control group (32). The measurement tools were applied before the study, to assert the equality of the two study groups. The experimental group was then exposed to the teaching strategy based on information technology, while the control group was exposed to traditional teaching methods, with the application of measurement tools in the study afterwards, to study the effectiveness of the proposed strategy.

\subsection{Instruments of the Study}

To achieve the objectives of the current study, the following tools were constructed to answer the first study question: What is the information technology-based strategy for developing creative writing skills and academic self-efficacy in English for university students? 
Most literature and previous studies on the practices and requirements of developing creative writing skills were analyzed, including Chen et al. (2019), Kostaris et al. (2017), Izquierdo et al. (2017), Saudi (2017), Musa (2016) and Al-Harbi (2015). Previous studies in the field of applying information technology into teaching and learning processes were analyzed, including the Salem study (2006) and Ghanem study (2018). A group of foundations for building the proposed strategy were extrapolated according to the following:

- The processes of developing creative writing skills in English requires training students on self-regulation skills, because of their significant impact on planning, reviewing and self-evaluating the writing process by students.

- The processes of developing and measuring students' creative writing skills at university level also requires building students' motivation, through a sense of achievement and improving academic self-efficacy, training students to plan written educational situations, and taking responsibility for their learning, with the provision of simulation models and training in creative writing skills, and training in the mental processes associated with thinking and the modification of thought pathways to produce diverse and unique ideas.

- Academic self-efficacy is one of determinants of creative writing skills for students at the undergraduate level, raising their level through interactive teaching strategies, with a supportive environment for the student to self-assume responsibility for his learning and planning his desired educational goals according to his abilities and real experiences.

- Activating information technology is connected to being an integral part of the university learning environment with its human and material components, including programs and courses, besides the need to provide digital content and educational platforms for students, build educational and knowledge societies from students and faculty members, and make the student the focus of academic work, while diversifying teaching and open sources of knowledge, especially digital.

Based on the nature of creative writing skills in English, steps of the proposed strategy have been described according to the following Table 1.

Table 1. Steps of proposed strategy

\begin{tabular}{|c|c|c|}
\hline $\mathbf{N}^{\circ}$ & Steps of Proposed Strategy & Teaching and Instructional Practices \\
\hline 1 & Activation stage & $\begin{array}{l}\text { The topic of writing is presented with a discussion and brainstorming session designed with } \\
\text { students to produce ideas, identify main and sub-ideas, and define a set of writing criteria: the } \\
\text { main paragraph in the article, the central sentences in paragraphs, punctuation marks, the subject } \\
\text { of the verb in the sentences, adherence to linguistic rules, formulations and structures, gradation } \\
\text { and sequence in ideas, the paragraph includes one main idea, the summary sentence at the end of } \\
\text { the paragraph, and the summary paragraph at the end of the article, taking into consideration the } \\
\text { standards of creative writing in the production of ideas, their diversity and originality. }\end{array}$ \\
\hline 2 & Search and study stage & $\begin{array}{l}\text { Directing students to an educational journey through the web in the educational platform, digital } \\
\text { library, some digital resources, or a free journey through the Internet, to read about the topic, its } \\
\text { dimensions and importance, and to know the ideas that were identified in the previous stage in } \\
\text { broadness and depth. }\end{array}$ \\
\hline 3 & Writing frame design stage & $\begin{array}{l}\text { A discussion forum is designed to build a learning community of students within the division, or } \\
\text { to employ social media applications, or to apply discussion forums through the educational } \\
\text { platform within the university, to discuss what students have reached in the previous research } \\
\text { stage, and to organize ideas and establish a general framework for writing the topic in a creative } \\
\text { way, responding to students' inquiries and guiding students to write creatively about the topic. }\end{array}$ \\
\hline 4 & $\begin{array}{l}\text { Digital publishing stage for } \\
\text { written creativity }\end{array}$ & $\begin{array}{l}\text { Directing students to publish what they have learned through a digital magazine, blog, platform or } \\
\text { exhibition that is designed for display, reading and criticism. }\end{array}$ \\
\hline 5 & Final evaluation stage & $\begin{array}{l}\text { The results of the assessment are used in the previous stage to rewrite the subject and to train to } \\
\text { use the creative writing criteria correctly. Creative writing course is repeated in another topic. }\end{array}$ \\
\hline
\end{tabular}

Seven teaching plans were prepared that were related to creative writing skills in the course (English 102), where the general objective of the course is related to the development of English language skills among students. It includes academic reading and writing skills, simulation models in creative writing, and training students on creative writing skills in a gradual way, from writing sentences and ideas to writing paragraphs and articles.

\section{Creative Writing Skills Test}

To measure creative writing skills, many previous studies were analyzed, including (Temizkan, 2011), Al-Harbi 
(2015, p. 238), Zain Al-Din and Al-Jarrah (2016, p. 149), Al-Naimi (2017, p. 91), and Ramon-Casas et al. (2019). All studies confirmed the possibility of measuring creative writing skills through a test type of specific or open essay questions, according to a set of indicators, and the test was constructed according to the steps that follow.

Objective of the test: The test was associated with measuring the creative writing skills of undergraduate students in the components of fluency, flexibility, and originality.

Test content: It was possible to determine test content by analyzing writing skills in light of the three components of creativity (fluency, flexibility, and originality) in English. The current test measures the areas and indicators shown in the following Table 2.

Table 2. Components and indicators for measuring creative writing

\begin{tabular}{lll}
\hline $\mathbf{N}^{\circ} \quad$ Skills & Scale Indicators \\
\hline 1 & Fluency in writing & Writing the largest number of main ideas on a specific topic. \\
& Writing the largest number of sub-ideas about a main idea. \\
& Writing as many sentences as possible about a sub-idea. \\
& Writing the largest number of words according to specific criteria. \\
& Writing the largest number of sentences synonymous with the introductory sentence. \\
& Writing the largest number of sentences contradicting a given sentence. \\
& Writing the largest number of synonyms for a specific word. \\
& Writing the largest number of antonyms for a specific word. \\
& Writing the largest number of solutions for a specific problem. \\
& Writing the largest number of different main ideas about a particular topic or situation. \\
& Writing the largest number of different and distinct main ideas on a particular topic or situation. \\
& Writing as many different and distinct sub-ideas around a main idea. \\
& Writing the largest number of different and distinct sentences about a specific idea. \\
& Writing the largest number of different and distinct words according to specific criteria. \\
& Writing the largest number of differentiated and distinct sentences synonymous with the \\
& introductory sentence. \\
& Writing the largest number of different and distinct sentences that contradict a given sentence. \\
& Writing the largest number of different and distinct words that are synonymous with a specific word. \\
& Writing the largest number of different and distinct words opposite to a specific word. \\
& Writing as many different and distinct solutions connected to a specific problem.
\end{tabular}

In the case of writing open topics, creative writing skills related to the following skills are taken into consideration:

- Linguistic skills in creative writing: grammar skills, styles and structures, spelling, punctuation, organizing the content of the topic, coherence of ideas, good style, use of linking tools, accuracy of meaning, with linguistic formulation.

- Productive skills: diversity of ideas and their interrelationship, building the topic in a comprehensive, directed introduction, linking paragraphs with main ideas, presenting and explaining the main ideas, and summarizing the topic in a concluding paragraph.

- Organizational skills: These skills are related to the need to adhere to writing standards as much as possible, in terms of quantity, writing form and good handwriting. These practices are directed to students through educational activities in the proposed strategy for the implementation of the course.

The test included (9) essay questions, which began with short-answer questions, but with open solutions. For example, write the largest number of synonyms for the word "study". The test also included questions that required building a paragraph around a specific sub-idea, and a long essay topic that required production and organization. The concentration was on estimating the scores for each question according to the following Table 3. 
Table 3. Estimating student scores in creative writing skills test

\begin{tabular}{lll}
\hline Creative Writing Skills & Calculating Marks \\
\hline$>$ & Write the largest number of main ideas on a specific topic. & Fluency: a score for each idea, sentence, \\
$>$ & Write the largest number of sub-ideas around a main idea. & or word \\
$>$ & Write the largest number of sentences about a sub-idea. & Flexibility: a score for each different \\
$>\quad$ Write the largest number of words according to specific criteria. & idea, sentence, or word \\
$>\quad$ Write the largest number of sentences synonymous with the introduction sentence. & Originality: A score for each idea, \\
$>\quad$ Write the largest number of the sentence with a given sentence. & sentence, or word that is less than 5\% \\
$>\quad$ Write the largest number of synonyms for a specific word. & common among students \\
$>\quad$ Write as many antonyms as possible for a given word. & \\
$>\quad$ Write as many solutions as possible to a specific problem. &
\end{tabular}

The test included two parts in its initial form: the first was linked to the basic data of the students and included instructions for applying the test and response instructions; the second part included the test vocabulary.

\subsection{Validity and Reliability of the Test}

Since validity indicates that the tool measures what it was used to assess and the correlation of vocabulary with the objective of the test, the test was presented to (6) specialists in language acquisition, teaching methods and psychometrics, in order to examine the extent to which vocabulary is related to measuring creative writing skills, the suitability of vocabulary for a study sample, and to express an opinion on the linguistic formulation of the test vocabulary. Some observations were made according to the opinions of the jury members. To measure the internal consistency of the test vocabulary, the test was conducted on a sample of (33), in addition to the basic sample of the study, and the Pearson correlation coefficient was calculated between the skill score in each question and the total score of the main skill.

The values of the correlation coefficient varied between the two values $(0.627-0.809)$, which are function values at the level $(0.01)$ and values that indicate a positive correlation that varied between a medium and strong positive relationship, besides which a high level of internal consistency of the test items was adopted. The stability of the test was also measured using the Cronbach alpha coefficient, and the results are in the following table.

Table 4. Cronbach's Alpha Coefficients to measure stability of creative writing skills test

\begin{tabular}{llll}
\hline $\mathrm{N}^{\circ}$ & Creative Writing Skills & Number of Items & Cronbach's Alpha Coefficients \\
\hline 1 & Fluency in writing & 9 & 0.843 \\
2 & Flexibility in writing & 9 & 0.819 \\
3 & Originality in writing & 9 & 0.757 \\
Total Creative Writing Skills & 9 & 0.859 \\
\hline
\end{tabular}

Table 4 shows that the values of Cronbach's alpha coefficients are acceptable, indicating the validity of the test for use in the current study. The test was constructed in the final form applicable to field experimentation.

\subsection{Academic Self-Efficacy Scale}

Studies that connected with self-concept and its components and academic self-efficacy were extrapolated and analyzed, including Peiffer et al. (2019) and Gorges and Hollmann (2019), which indicated the possibility of building a scale to measure academic self-efficacy. The scale aimed to measure a university student's level of self-efficacy in English, which is related to his level of motivation and enthusiasm in learning English and building language skills; and academic writing, measuring the student's level of confidence in his own abilities, and the extent to which he developed his habits of studying English lessons. The content of the scale was related to a group of dimensions, as in the following Table 5. 
Table 5. Describing dimensions of academic self-efficacy scale in English

\begin{tabular}{|c|c|c|c|}
\hline $\mathbf{N}^{\circ}$ & Dimensions & Operational Description & Number of items \\
\hline 1 & $\begin{array}{l}\text { Student self-motivation to } \\
\text { learn }\end{array}$ & $\begin{array}{l}\text { Student motivation to learn English, the level of attention and enthusiasm in } \\
\text { performing educational tasks and activities. }\end{array}$ & 5 \\
\hline 2 & $\begin{array}{l}\text { Student's confidence in the } \\
\text { ability to achieve }\end{array}$ & $\begin{array}{l}\text { Student's confidence in his abilities and previous experiences in English, and } \\
\text { his confidence in efficiency of English teaching practices in improving his } \\
\text { achievement levels. }\end{array}$ & 7 \\
\hline 3 & $\begin{array}{l}\text { Perseverance and continuity } \\
\text { in learning }\end{array}$ & $\begin{array}{l}\text { Student's attempt to learn and face failure, continuity of effort, and } \\
\text { willingness to search for different ways and methods in building language } \\
\text { skills. }\end{array}$ & 6 \\
\hline 4 & $\begin{array}{l}\text { Self-regulation of learning } \\
\text { and recall habits }\end{array}$ & $\begin{array}{l}\text { Student's ability to plan learning processes, study and meet his needs, } \\
\text { assimilate his learning styles, methods for recalling and retrieving } \\
\text { educational experiences. }\end{array}$ & 7 \\
\hline \multicolumn{3}{|c|}{ Academic Self-Efficacy Scale } & 25 \\
\hline
\end{tabular}

Items of the scale were written, taking into consideration its diversity in a positive/negative way. The five-point Likert scale (always $=5$ degrees, often $=4$ degrees, sometimes $=3$ degrees, rarely $=2$ degrees, never $=1$ degree) was used in the positive items; the scale was written in its initial form, which consists of two parts, the first part included the student's data and instructions for applying the scale and responding to its items, while the second part included items of the scale.

\subsection{Validity and Stability of the Scale}

To measure the apparent validity of the scale, it was presented to a group of jury members to express their opinion about the correlation of the scale's items with the axis that falls below it, the item's correlation with the academic self-efficacy scale as a whole, and the appropriate duration of the scale for learning English in university, while ensuring linguistic accuracy.

In the light of opinions of the jury members, observations were conducted and the scale applied on a sample of (33) English department students. The degree of each individual and the total score for the axis was calculated, and the Pearson correlation coefficients were limited between the values (0.581-0.877). Awareness of values indicated that there is a positive correlation varied between medium to high; it is statistically significant at the level $(\alpha \leq 0.01)$ and indicates the internal consistency of the scale items. To measure the stability of the scale, Cronbach's alpha coefficients were calculated for their suitability for one application, and the results are in the following Table 6 .

Table 6. Cronbach's Alpha Coefficients to measure stability of the academic self-efficacy scale

\begin{tabular}{llll}
\hline $\mathbf{N}^{\circ}$ & Dimensions of Academic Self-Efficacy Scale & Number of Items & Cronbach's Alpha Coefficients \\
\hline 1 & Self-motivation to learn & 5 & 0.653 \\
2 & Confidence in ability to accomplish & 7 & 0.823 \\
3 & Perseverance and continuity in learning & 6 & 0.774 \\
4 & Self-regulation of learning and recall & 7 & 0.801 \\
Total Academic Self-Efficacy Scale & $\mathbf{2 5}$ & $\mathbf{0 . 8 5 5}$ \\
\hline
\end{tabular}

Table 6 shows that the values of Cronbach's alpha coefficients are acceptable, indicating the validity of the academic self-efficacy scale for practical application in the current study. The scale was constructed into the final form applicable to field experimentation.

\subsection{Practical Application Procedures}

Practical application procedures were conducted in in the first semester of the academic year 1439/1440 AD, on course (English 102), for students of the second year at the university. The practical application procedures began with the pre-application of the research tools, to ensure that the experimental and control groups were equal. The results of the pre-application are shown in Table 7 below, including arithmetic averages, standard deviations, and t-test results for the two uncorrelated groups. 
Table 7. Differences between creative writing scores of both groups in pre-application

\begin{tabular}{|c|c|c|c|c|c|c|c|}
\hline $\begin{array}{l}\text { Creative Writing } \\
\text { Skills }\end{array}$ & Group & Sample & $\begin{array}{l}\text { Arithmetic } \\
\text { Average }\end{array}$ & $\begin{array}{l}\text { Standard } \\
\text { Deviation }\end{array}$ & T-Value & $\begin{array}{l}\text { Degrees of } \\
\text { Freedom }\end{array}$ & $\begin{array}{l}\text { Statistical } \\
\text { Significance }\end{array}$ \\
\hline \multirow[t]{2}{*}{ Fluency in writing } & Experimental & 32 & 9.156 & 1.019 & 1.548 & 62 & 0.127 \\
\hline & Control & 32 & 9.531 & 0.915 & & & \\
\hline \multirow[t]{2}{*}{ Flexibility in writing } & Experimental & 32 & 2.563 & 0.840 & 0.570 & 62 & 0.571 \\
\hline & Control & 32 & 2.438 & 0.913 & & & \\
\hline \multirow[t]{2}{*}{ Originality in writing } & Experimental & 32 & 1.001 & 0.718 & 0.680 & 62 & 0.499 \\
\hline & Control & 32 & 1.125 & 0.751 & & & \\
\hline \multirow[t]{2}{*}{ Total test } & Experimental & 32 & 12.791 & 1.727 & 0.837 & 62 & 0 \\
\hline & Control & 32 & 13.094 & 1.855 & & & \\
\hline
\end{tabular}

Table 7 confirms that the arithmetic averages converge between the students of the experimental and control groups in the creative writing skills test in general and its skills separately. It is clear from the calculated (T) values that the differences are not statistically significant at the level of significance $(\alpha \leq 0.01)$ in the test in general and its skills separately. This indicates that the students of the experimental and control groups are equal in previous experiences related to creative writing skills, before the experiment and the application of educational materials.

Arithmetic averages, standard deviations and T-test results for the two uncorrelated groups are shown in Table 8 below, to study the differences between the academic self-efficacy scores of the experimental and control groups in the pre-application of the creative writing skills test.

Table 8. Differences between academic self-efficacy scores in pre-application

\begin{tabular}{|c|c|c|c|c|c|c|c|}
\hline $\begin{array}{l}\text { Dimensions of Academic } \\
\text { Self-Efficacy }\end{array}$ & Group & Sample & $\begin{array}{l}\text { Arithmetic } \\
\text { Average }\end{array}$ & $\begin{array}{l}\text { Standard } \\
\text { Deviation }\end{array}$ & T-Value & $\begin{array}{l}\text { Degrees of } \\
\text { Freedom }\end{array}$ & $\begin{array}{l}\text { Statistical } \\
\text { Significance }\end{array}$ \\
\hline \multirow[t]{2}{*}{ Self-motivation to learn } & Experimental & 32 & 9.656 & 1.450 & 0.260 & 62 & 0.796 \\
\hline & Control & 32 & 9.750 & 1.436 & & & \\
\hline \multirow{2}{*}{$\begin{array}{l}\text { Confidence in ability to } \\
\text { accomplish }\end{array}$} & Experimental & 32 & 12.718 & 1.651 & 0.485 & 62 & 0.630 \\
\hline & Control & 32 & 12.531 & 1.437 & & & \\
\hline \multirow{2}{*}{$\begin{array}{l}\text { Perseverance \& continuity } \\
\text { in learning }\end{array}$} & Experimental & 32 & 11.281 & 1.727 & 0.232 & 62 & 0.817 \\
\hline & Control & 32 & 11.168 & 1.490 & & & \\
\hline \multirow{2}{*}{$\begin{array}{l}\text { Self-regulation of learning } \\
\& \text { recall }\end{array}$} & Experimental & 32 & 12.781 & 1.717 & 0.246 & 62 & 0.807 \\
\hline & Control & 32 & 12.688 & 1.306 & & & \\
\hline \multirow[t]{2}{*}{ Total scale } & Experimental & 32 & 46.438 & 3.330 & 0.384 & 62 & 0.702 \\
\hline & Control & 32 & 46.156 & 2.464 & & & \\
\hline
\end{tabular}

Table 8 explains the convergence of the arithmetic averages between students of the experimental and control groups in the measure of academic self-efficacy in general and in each axis separately. It is clear from the calculated $(T)$ values that the differences are not statistically significant at the level of significance $(\alpha \leq 0.01)$ in degrees of freedom (62) in general, also in its dimensions separately. This indicates the equality of students in both experimental and control groups in the levels of academic self-efficacy before the experiment and the application of educational materials.

After verifying the equivalence of experimental and control study groups, the practical application procedures were completed and the two study groups were subjected to treatments: the experimental group was exposed to the teaching course using the proposed strategy, while the control group was exposed to the usual strategy. It was noticed that students in the experimental group showed a high degree of enthusiasm, motivation and attention, especially in regard to the educational activities included in the strategy and related to the development of creative writing skills, in addition to the inclusion of the strategy into research and thinking processes that fit their needs.

The experiment procedures were carried out throughout the semester. At the end of the experiment, the creative writing skills test and the academic self-efficacy scale were applied, for the purpose of studying the differences and studying the impact of the proposed strategy based on information technology in developing creative writing skills and developing students' academic self-efficacy levels. 


\section{Statistical Processing}

To answer the questions of the current study and test the validity of its hypotheses, the study relied on a set of descriptive and inferential (parametric) statistical treatments, including:

- Descriptive treatments: the arithmetic mean and standard deviation manipulations to describe the data.

- Inferential treatments: to measure statistical significance. The t-test for two uncorrelated groups was used to study the differences between the experimental and control groups, and the t-test for the two related groups, to study the statistical significance differences between the pre and post applications.

- Measurement of educational significance: using the effect size to study the significance and educational importance of the independent variable in the development of dependent variables. The Pearson correlation coefficient test was used to study the type and degree of correlation between creative writing skills and academic self-efficacy, in addition to using the coefficient of determination to study the educational importance of the type and degree of correlation.

- Treatment tools: for measuring the validity and reliability of the study tools (Pearson correlation coefficient and Alpha Cronbach coefficient).

\section{Presentation and Discussion of Study Results}

To answer the second study question: What is the impact of the information technology-based strategy on developing creative writing skills in English for university students? Hypotheses 1 and 2 were tested:

Hypothesis 1: There are statistically significant differences at level $(\alpha \leq 0.01)$ between the mean scores of students from experimental and control groups in the post application for testing creative writing skills in general, and each skill separately, in favor of the experimental group.

To test the validity of Hypothesis 1 , the arithmetic means and standard deviations were calculated, and the value of $(\mathrm{T})$ was calculated for the two uncorrelated groups, to study the differences between scores of the experimental and control groups. See results in following Table 9.

Table 9. Results for uncorrelated groups in the post application of creative writing skills test

\begin{tabular}{lllllllll}
\hline $\begin{array}{l}\text { Creative Writing } \\
\text { Skills }\end{array}$ & Group & Sample & $\begin{array}{l}\text { Arithmetic } \\
\text { Average }\end{array}$ & $\begin{array}{l}\text { Standard } \\
\text { Deviation }\end{array}$ & T-Value & $\begin{array}{l}\text { Degrees of } \\
\text { Freedom }\end{array}$ & $\begin{array}{l}\text { Statistical } \\
\text { Significance }\end{array}$ & $\begin{array}{l}\text { Effect } \\
\text { Size }\end{array}$ \\
\hline Fluency in writing & Experimental & 32 & 31.406 & 2.563 & 35.694 & 62 & $0.000^{* *}$ & 6.309 \\
& Control & 32 & 12.344 & 1.598 & & & & \\
Flexibility in writing & Experimental & 32 & 21.469 & 2.577 & 30.596 & 62 & $0.000^{* *}$ & 5.408 \\
5 & Control & 32 & 4.906 & 1.653 & & & & \\
Originality in writing & Experimental & 32 & 9.250 & 1.218 & 29.256 & 62 & $0.000^{* *}$ & 5.571 \\
& Control & 32 & 2.062 & 0.669 & & & & \\
Total Test & Experimental & 32 & 62.125 & 4.022 & 51.544 & 62 & $0.000^{* *}$ & 9.111 \\
& Control & 32 & 19.313 & 2.482 & & & & \\
\hline
\end{tabular}

According to Table 9, there are differences between the arithmetic averages in scores of experimental and control groups, in favor of the experimental group, in testing creative writing skills in general and in each skill separately $(\alpha \leq 0.01)$ with degrees of freedom (62). Therefore, it is possible to accept the first oriented hypothesis that there are statistically significant differences at level $(\alpha \leq 0.01)$ between the mean scores of students from the experimental and control groups in the post application for testing creative writing skills in general, and each skill separately, in favor of the experimental group.

To measure the educational benefits or practical significance, the effect size was calculated to investigate the impact of the independent variable (the proposed strategy based on information technology) on development of the dependent variable (creative writing skills) in the case of the two uncorrelated groups.

Table 9 confirmed that the effect size is greater than the correct one (Murad, 2011, p. 244), which indicates the large size of the educational importance or the impact of the independent variable on the development of dependent variables, indicating the importance of using the strategy based on information technology in teaching English and its impact on developing creative writing skills in general and their skills separately.

Hypothesis 2: There are statistically significant differences at level $(\alpha \leq 0.01)$ between the mean scores of the experimental group of students in the pre and post applications for testing creative writing skills in general, and each skill separately, in favor of the experimental group. 
To examine the validity of the hypothesis, the value of $(\mathrm{T})$ was calculated for the two correlated groups as in the following Table 10.

Table 10. Results for correlated groups in pre and post applications of creative writing skills test

\begin{tabular}{|c|c|c|c|c|c|c|c|c|c|}
\hline \multirow{2}{*}{$\begin{array}{l}\text { Creative Writing } \\
\text { Skills }\end{array}$} & \multicolumn{2}{|l|}{ Pre-Marks } & \multicolumn{2}{|l|}{ Post-Marks } & \multirow{2}{*}{$\begin{array}{l}\text { Correlation } \\
\text { Coefficient }\end{array}$} & \multirow[t]{2}{*}{ T-Value } & \multirow{2}{*}{$\begin{array}{l}\text { Degrees of } \\
\text { Freedom }\end{array}$} & \multirow{2}{*}{$\begin{array}{l}\text { Statistical } \\
\text { Significance }\end{array}$} & \multirow{2}{*}{$\begin{array}{l}\text { Effect } \\
\text { Size }\end{array}$} \\
\hline & $\begin{array}{l}\text { Arithmetic } \\
\text { Average }\end{array}$ & $\begin{array}{l}\text { Standard } \\
\text { Deviation }\end{array}$ & $\begin{array}{l}\text { Arithmetic } \\
\text { Average }\end{array}$ & $\begin{array}{l}\text { Standard } \\
\text { Deviation }\end{array}$ & & & & & \\
\hline Fluency in writing & 9.156 & 1.019 & 31.706 & 2.563 & 0.074 & 44.500 & 31 & $0.000 * *$ & 10.705 \\
\hline Flexibility in writing & 2.563 & 0.840 & 21.469 & 2.577 & 0.232 & 42.456 & 31 & $0.000 * *$ & 9.301 \\
\hline Originality in writing & 1.001 & 0.718 & 9.250 & 1.218 & 0.221 & 36.474 & 31 & $0.000^{* *}$ & 8.108 \\
\hline Total Test & 12.719 & 1.727 & 62.125 & 4.022 & 0.120 & 61.237 & 31 & $0.000 * *$ & 14.361 \\
\hline
\end{tabular}

Table 10 explains that there are differences between arithmetic averages in the scores of the experimental group of students between the two applications (pre and post), in favor of the post application's scores in testing creative writing skills in general and in each skill separately. By extrapolating T-values of the two calculated correlated groups, the statistical significance of these differences is evident at level $(\alpha \leq 0.01)$ with degrees (31) of freedom.

Therefore, it is possible to accept the second directed hypothesis that there are statistically significant differences at level $(\alpha \leq 0.01)$ between the mean scores of the experimental group of students in the pre and post applications for testing creative writing skills in general, and each skill separately, in favor of the experimental group.

To measure the educational importance or practical significance, the effect size was calculated to investigate the impact of the independent variable (the proposed strategy based on information technology) on development of the dependent variable (creative writing skills), in the case of the two correlated groups. Table 10 asserts that the effect size is greater than one, which indicates the large size of the educational importance or the impact of the independent variable on the development of the dependent variables, and indicates the importance of using the strategy based on information technology in teaching English and its impact on developing creative writing skills in general and their skills separately.

To answer the third study question: What is the impact of the information technology-based strategy on academic self-development in English for university students? Hypotheses 3 and 4 were examined.

Hypothesis 3: There are statistically significant differences at level $(\alpha \leq 0.01)$ between the mean scores of students from the experimental and control groups in the post application of the academic self-efficacy scale in general, and each dimension separately, in favor of the experimental group.

To examine the validity of the hypothesis, the arithmetic means and standard deviations were calculated, and the value of $(\mathrm{T})$ was calculated for the two uncorrelated groups, as can be seen in the following Table 11.

Table 11. Results for uncorrelated groups in the post application of the academic self-efficacy scale

\begin{tabular}{|c|c|c|c|c|c|c|c|c|}
\hline $\begin{array}{l}\text { Academic } \\
\text { Self-Efficacy }\end{array}$ & Group & Sample & $\begin{array}{l}\text { Arithmetic } \\
\text { Average }\end{array}$ & $\begin{array}{l}\text { Standard } \\
\text { Deviation }\end{array}$ & T-Value & $\begin{array}{l}\text { Degrees of } \\
\text { Freedom }\end{array}$ & $\begin{array}{l}\text { Statistical } \\
\text { Significance }\end{array}$ & $\begin{array}{l}\text { Effect } \\
\text { Size }\end{array}$ \\
\hline \multirow{2}{*}{$\begin{array}{l}\text { Self-motivation to } \\
\text { learn }\end{array}$} & Experimental & 32 & 21.656 & 1.557 & 22.363 & 62 & $0.000^{* *}$ & 3.953 \\
\hline & Control & 32 & 13.594 & 1.316 & & & & \\
\hline \multirow{2}{*}{$\begin{array}{l}\text { Confidence in ability } \\
\text { to achieve }\end{array}$} & Experimental & 32 & 31.094 & 1.552 & 38.381 & 62 & $0.000^{* *}$ & 6.874 \\
\hline & Control & 32 & 15.719 & 1.650 & & & & \\
\hline \multirow{2}{*}{$\begin{array}{l}\text { Perseverance and } \\
\text { continuity in learning }\end{array}$} & Experimental & 32 & 25.875 & 1.288 & 29.028 & 62 & $0.000^{* *}$ & 5.131 \\
\hline & Control & 32 & 14.625 & 1.733 & & & & \\
\hline \multirow{2}{*}{$\begin{array}{l}\text { Self-regulation of } \\
\text { learning and recall }\end{array}$} & Experimental & 32 & 31.906 & 1.367 & 32.827 & 62 & $0.000^{* *}$ & 5.803 \\
\hline & Control & 32 & 17.031 & 2.162 & & & & \\
\hline \multirow[t]{2}{*}{ Total Scale } & Experimental & 32 & 110.531 & 3.068 & 54.219 & 62 & $0.000^{* *}$ & 9.858 \\
\hline & Control & 32 & 60.969 & 4.161 & & & & \\
\hline
\end{tabular}

According to Table 11, there are differences between arithmetic averages in students' scores in experimental and control groups in favor of the experimental group, in the academic self-efficacy scale in general and in each skill separately. By extrapolating the computed T-values in the case of the two uncorrelated groups, the statistical 
significance of these differences is evident at the level $(\alpha \leq 0.01)$ with (62) degrees of freedom.

Therefore, it is possible to accept the third directed hypothesis: There are statistically significant differences at level $(\alpha \leq 0.01)$ between mean scores of students from the experimental and control groups in the post application of the academic self-efficacy scale in general, and each dimension separately, in favor of the experimental group.

For measuring the educational benefits or practical significance, the effect size was calculated to investigate the impact of the independent variable (the proposed strategy based on information technology) on the development of the dependent variable (academic self-efficacy) in the case of the two uncorrelated groups.

Table 11 explains that effect size is greater than one, which indicates the large size of educational importance or the impact of the independent variable on the development of dependent variables, and indicates the importance of applying the strategy based on information technology in English and its impact on developing academic self-efficacy in general and its dimensions separately.

Hypothesis 4: There are statistically significant differences at level $(\alpha \leq 0.01)$ between the mean scores of the experimental group in the pre and post applications of the academic self-efficacy scale in general, and each dimension separately, in favor of the experimental group.

To examine the validity of Hypothesis 4, the ( $\mathrm{T}$ ) value was calculated for the two correlated groups as can be seen in Table 12.

Table 12. Results for correlated groups in pre and post applications of academic self-efficacy scale

\begin{tabular}{|c|c|c|c|c|c|c|c|c|c|}
\hline \multirow{2}{*}{$\begin{array}{l}\text { Academic } \\
\text { Self-Efficacy }\end{array}$} & \multicolumn{2}{|l|}{ Pre- Marks } & \multicolumn{2}{|l|}{ Post-Marks } & \multirow{2}{*}{$\begin{array}{l}\text { Correlation } \\
\text { Coefficient }\end{array}$} & \multirow[t]{2}{*}{ T-Value } & \multirow{2}{*}{$\begin{array}{l}\text { Degrees } \\
\text { of } \\
\text { Freedom }\end{array}$} & \multirow{2}{*}{$\begin{array}{l}\text { Statistical } \\
\text { Significance }\end{array}$} & \multirow{2}{*}{$\begin{array}{l}\text { Effect } \\
\text { Size }\end{array}$} \\
\hline & $\begin{array}{l}\text { Arithmetic } \\
\text { Average }\end{array}$ & $\begin{array}{l}\text { Standard } \\
\text { Deviation }\end{array}$ & $\begin{array}{l}\text { Arithmetic } \\
\text { Average }\end{array}$ & $\begin{array}{l}\text { Standard } \\
\text { Deviation }\end{array}$ & & & & & \\
\hline $\begin{array}{l}\text { Self-motivation to } \\
\text { learn }\end{array}$ & 9.656 & 1.450 & 21.656 & 1.557 & 0.168 & 29.513 & 31 & $0.000 * *$ & 6.729 \\
\hline $\begin{array}{l}\text { Confidence in } \\
\text { ability to achieve }\end{array}$ & 12.718 & 1.651 & 31.094 & 1.552 & 0.103 & 43.686 & 31 & $0.000 * *$ & 10.343 \\
\hline $\begin{array}{l}\text { Perseverance and } \\
\text { continuity in } \\
\text { learning }\end{array}$ & 11.281 & 1.727 & 25.875 & 1.288 & 0.321 & 46.029 & 31 & $0.000^{* *}$ & 9.842 \\
\hline $\begin{array}{l}\text { Self-regulation of } \\
\text { learning and recall }\end{array}$ & 12.781 & 1.717 & 31.906 & 1.376 & 0.155 & 53.346 & 31 & $0.000 * *$ & 12.259 \\
\hline Scale total & 46.438 & 3.330 & 110.531 & 3.068 & 0.169 & 87.793 & 31 & $0.000 * *$ & 20.007 \\
\hline
\end{tabular}

Table 12 explains that there are differences between the arithmetic averages in the scores of the experimental group of students between the two applications, pre and post, in favor of the marks of the post application in the academic self-efficacy scale in general, and in each skill separately, at level $(\alpha \leq 0.01)$ with degrees of freedom (31), so it was possible to accept the fourth directed hypothesis.

There are statistically significant differences at level $(\alpha \leq 0.01)$ between the mean scores of the experimental group of students in the two applications, pre and post, in the academic self-efficacy scale in general, and each dimension separately, in favor of the experimental group students.

To measure the educational importance or practical significance, the effect size was calculated to investigate the impact of the independent variable (the proposed strategy based on information technology) on the development of the dependent variable (academic self-efficacy scale), in the case of the two correlated groups. It is clear from Table 12 that the effect size is greater than unity, which indicates the great size of the educational importance or the impact of the independent variable on development of the dependent variables, and indicates the importance of using the strategy based on information technology in teaching English and its impact on the development of academic self-efficacy in general and its dimensions separately.

To answer the fourth question: What is the type and level of the correlation between students'scores in creative writing skills and their scores on the Academic Self-Efficacy Scale in English? the fifth hypothesis was tested.

Hypothesis 5: There is a positive correlation between the scores of the experimental group in favor of the post application of the creative writing test and their scores on the academic self-efficacy scale.

To examine the validity of the hypothesis, the Pearson correlation coefficient was calculated. The results for the 
creative writing test and the academic self-efficacy scale can be seen in the following Table 13.

Table 13. Pearson correlation coefficient results in the post application

\begin{tabular}{llllll}
\hline $\begin{array}{l}\text { Coefficient of } \\
\text { Determination }\end{array}$ & $\begin{array}{l}\text { Indication } \\
\text { Level }\end{array}$ & Type and Degree & $\begin{array}{l}\text { Pearson Correlation } \\
\text { Coefficient }\end{array}$ & Sample & Relationship Dimensions \\
\hline 0.968 & 0.000 & Strong positive & 0.984 & 32 & $\begin{array}{l}\text { Creative writing } \\
\text { skills-Academic self-efficacy }\end{array}$ \\
\hline
\end{tabular}

Table 13 confirms that there is a strong positive correlation between scores of the experimental group of students in the post application of the creative writing skills test and their scores in post application of the academic self-efficacy scales shown in Table 12, with the statistical significance of the correlation at the level $(\alpha \leq 0.01)$. Through the current result, it was possible to accept the fifth hypothesis: There is a positive correlation between the scores of the experimental group in favor of the post application of the creative writing test and their scores on the academic self-efficacy scale.

In order to study the educational significance of the positive and strong correlation, the coefficient of determination or the correlation ratio between two variables was calculated, which represents the ratio of covariance between two dependent variables. The coefficient of determination was calculated by finding the square of the correlation coefficient. Table 13 shows that $96.8 \%$ of the variance of one of the two dependent variables (creative writing skills or self-academic efficacy) can be explained with the knowledge of the second variable, while the remaining percentage (3.2\%) is attributed to other variables. The covariance ratio between the two variables indicates the strong relationship, also the possibility of explaining each of two variables to the other.

According to the above findings, the study reached an answer to all of the study questions and concluded the following:

- There are statistically significant differences at level $(\alpha \leq 0.01)$ between the mean scores of the experimental and control groups of students in the post application of the test in creative writing skills in general, and each skill separately, in favor of the students from the experimental group.

- There are statistically significant differences at level $(\alpha \leq 0.01)$ between the mean scores of the experimental group of students in the pre and post applications for the creative writing skills test in general, and each skill separately, in favor of the experimental group of students.

- There are statistically significant differences at level $(\alpha \leq 0.01)$ between the mean scores of the experimental and control groups of students in the post application of the academic self-efficacy scale in general, and each dimension separately, in favor of the students from the experimental group.

- There are statistically significant differences at level $(\alpha \leq 0.01)$ between the mean scores of the experimental group of students in the pre and post applications of the academic self-efficacy scale in general, and each dimension separately, in favor of the experimental group of students.

- There is a positive correlation between the experimental group's scores in the post application of the creative writing test and their scores on the academic self-efficacy scale.

This result is consistent with the results of studies by Wang et al. (2019) and Al-Mazoughi, Saleh and Shehata (2019), which showed the effectiveness of teaching focused on information technology in developing creative writing skills. It is also consistent with the results of the studies by Rakhmatullina (2019) and Niculescu and Obilişteanu (2016), which showed the effectiveness of foreign language teaching centered on information technology.

The results of the current study also agree with the results of studies by Nasr, Farraj and Suleiman (2019), Healey (2019), Qhouf (2018), Saudi (2017), Al-Tuwairqi (2017), Al-Harbi (2015), and Abu Frash (2013), which emphasized the importance of having programs and strategies related to the development of creative writing skills within language skills. This concentration on practices of training students to read freely on multiple topics, ensures the building of a fertile imagination to generate main and subsidiary ideas in multiple paths, while promoting habits of perseverance in learning.

Results of the current study are also in agreement with Al-Rasheed (2019), Gorges and Hollmann (2019), Ghanem (2018), as well as the results of Ahmed study (2016) on the development of academic self-efficacy. Studies emphasized the importance of intentionality, planning for the development of self-concept and academic 
self-dimensions, as well as the importance of designing real life situations or real problems, designing cognitive journeys across the web, training students on self-organization habits - habits of study, and habits of mind. These practices increase the dimensions of academic self-efficacy, including motivation and levels of attention, and increase a student's academic self-confidence, experiences and cognitive abilities, while increasing his confidence in the nature of the English language, its relationship to his real problems, and strengthening him in meeting his needs.

The current study also agrees with results of Adeyemi and Erhuvwu (2020) and Ali (2017), which emphasized the correlation between academic self-efficacy and creative abilities, as they showed that improving levels of academic self-efficacy increases a student's confidence in his abilities while improving his levels of motivation, which is reflected in his levels of academic achievement and the increase of his creativity in many areas.

It is consistent with results of Khawaldeh study (2020) and the results of studies by Akinloye et al. (2020), Abu Al-Roos (2015), Ghareeb (2013), Al-Zayni and Abdel-Aziz (2010), which demonstrated the importance and effectiveness of applying information technology-based teaching strategies in teaching English language (also developing language skills in general) and its importance for the development of each skill of language building (and academic writing). Furthermore, results of the study also showed the effectiveness of teaching based on information technology in teaching language in general, and development of each skill separately, as information technology provides fertile educational opportunities that allow access to building knowledge requirements for writing skills in general, and creative writing skills in particular.

Information technology also allows simulation, modeling of writing skills, and continuous training, with exchanges of outputs in creative writing to assess the pathways of thinking and writing.

In general, it was concluded that designing teaching strategies based on the use of information technology in its various forms and tools is in parallel with these strategies in teaching English, as it has a significant impact on developing creative writing skills, while developing dimensions of academic self-efficacy among undergraduate students.

\section{Recommendations of the Study}

Through the importance and results of the study, the following recommendations were formulated:

- Planning professional development programs for university staff members in light of the use of information technology to build capacities about its use in teaching.

- Building the capacities of university staff members specialized in teaching English language courses in developing and measuring creative writing skills, as an important language building skill, with the necessity to focus on developing and measuring dimensions of academic self-efficacy.

- Including English courses in educational situations, activities and exercises based on information technology to develop and measure creative writing skills.

- Planning practices for developing and measuring academic self-efficacy with its dimensions as one of the directives to improve levels of achievement in many academic skills, including creative writing skills in English.

\section{Further Research Proposals}

In light of limitations of the study and results, it was possible to identify a group of research proposals as follows:

- Investigating the effectiveness of information technology-based strategies in developing critical reading skills in English for undergraduate students.

- Studying the obstacles for employing information technology in teaching and learning, according to the point of view of faculty staff members in Saudi universities.

- Implementing information technology-based teaching in developing many academic variables in English courses for university students.

\section{References}

Abu, A.-R., \& Adel, M. I. (2015). The effectiveness of blended learning in developing creative reading skills for Arabic language learners who speak other languages. Specialized International Educational Magazine: Dar Simat for Studies and Research, 4(7), 1-22. https://doi.org/10.12816/0025202

Abu, F., \& Hussein, M. (2013). The effectiveness of an educational program in creative writing based on 
cognitive theory in developing creative thinking and creative writing skills among gifted students in King Abdullah II Schools for Excellence. Unpublished doctoral dissertation. International University of Islamic Sciences, Amman.

Adeyemi, F., \& Erhuvwu, O. (2020). Self-Concept as a Predictor of Academic Achievement of Senior Secondary School Student in Mathematics. IFE Psychology, 28(2), 100-106.

Ahmed, S. A. A. (2016). The effectiveness of a proposed training program based on information processing theory in developing self-organized learning strategies, academic self-adequacy skills, and goal-orientation among student teachers at the College of Education. Arab Studies in Education and Psychology: Arab Educators Association, 70, 81-141.

Akinloye, G., Adu, E., Adu, K., \& Olawumi, K. (2020). Information and Communications Technology (ICT) and Teaching-Learning Capacity: The Classroom Management Interconnectivity. E-BANGI Journal, 17(7), $13-30$.

Al Mukhallafi, T. (2019). Attitudes and Usage of MALL Among Saudi University EFL Students. International Journal of English Linguistics, 9(1), 407. https://doi.org/10.5539/ijel.v9n1p407

Al-Harbi, K. b. H. (2015). A proposed program to develop creative writing skills for secondary school students, Reading and Knowledge Magazine: Ain Shams University - Faculty of Education. Egyptian Association for Reading and Knowledge, 165, 217-247.

Al-Mazoughi, K. M., Saleh, M. M., \& Shehata, H. S. (2019). A program in extended reading based on cognitive journeys to develop creative writing among secondary school students. Journal of Research in Language Teaching: Ain Shams University - College of Education. Educational Association for Language Teaching, 6, 60-82.

Al-Naimi, A. M., Al-Badri, A.-M. A., \& Al-Zayni, M. A.-S. (2017). The effectiveness of a proposed program based on integration of language arts in developing creative writing skills among student teachers at the College of Education in Iraq. Reading and Knowledge Magazine: Ain Shams University - Faculty of Education. Egyptian Association for Reading and Knowledge, 189, 86-117.

Al-Rasheed, L. S. (2019). The effectiveness of the problem-solving training program and its impact on developing the academic self-efficacy of university students. Arab Studies in Education and Psychology: Arab Educators Association, 114, 169-187.

Al-Tuwairqi, A. O. (2017). The effectiveness of a strategy based on habits of mind in developing creative writing skills for secondary school students. Published M.A thesis, Taif University, Taif.

Al-Zahrani, M. b. G. (2017). A program based on habits of mind to develop creative writing skills for first year secondary students. Studies in Curricula and Teaching Methods: Ain Shams University - Faculty of Education. Egyptian Association for Curriculum and Teaching Methods, 224, 159-210.

Al-Zayni, M. E.-S., \& Abdel-Aziz, Y. S. (2010). The effectiveness of an electronic program based on the blended learning strategy in developing the conversational skills of Arabic language learners who speak other languages: Educational Technology. Egyptian Association for Educational Technology, 20(1), 113-160.

Ali, M. A.-N. (2017). Academic self-concept and self-confidence and their relationship to creative abilities among talented Egyptian and Saudi students with learning disabilities: A cross-cultural study. International Journal of Educational and Psychological Sciences: The Arab Foundation for Scientific Research and Human Development, 8, 153-243.

Chen, M., Zhou, C., Meng, C., \& Wu, D. (2019). How to promote Chinese primary and secondary school teachers to use ICT to develop high-quality teaching activities. Educational Technology Research \& Development, 67(6), 1593-1611. https://doi.org/10.1007/s11423-019-09677-0

Ghanem, R. A. H. (2018). Developing the concepts of psychology and activating the academic self-using cognitive trips among student teachers in the Department of Psychology, Faculty of Education, Tanta University, Journal of the Faculty of Education: Tanta University. Faculty of Education, 71(3), 699-725.

Ghareeb, R. K. (2013). A proposed strategy based on the electronic achievement file to develop writing skills in English for middle school students in the State of Kuwait. Unpublished M.A thesis. Arabian Gulf University, Manama.

Gorges, J., \& Hollmann, J. (2019). The Structure of Academic Self-Concept When Facing Novel Learning Content: Multidimensionality, Hierarchy, and Change. Europe's Journal of Psychology, 15(3), 491-508. 
https://doi.org/10.5964/ejop.v15i3.1716

Hanna, C. Z. (2018). A proposed strategy based on information processing theory to develop creative writing skills for gifted students at the secondary stage. Reading and Knowledge Magazine: Ain Shams University Faculty of Education. Egyptian Association for Reading and Knowledge, 195, 1-46.

Hassanein, E. A. (2011). The effect of training on using some self-organized learning strategies on academic self-efficacy, test anxiety and academic achievement among secondary school students. The Egyptian Journal of Psychological Studies, 21(73), 45-88.

Healey, B. (2019). How children experience creative writing in the classroom. Australian Journal of Language \& Literacy, 42(3), 184-194.

Izquierdo, J., Cruz-villegas, V., Aquino-Zúñiga, S., Sandoval-Caraveo, M., \& García-Martínez, V. (2017). Teachers' Use of ICTs in Public Language Education: Evidence from Second Language Secondary-school Classrooms. Comunicar, 25(50), 33-41. https://doi.org/10.3916/C50-2017-03

Khawaldeh, I. I. (2020). Perceptions of English language teachers in the basic stage about integrating information and communication technology in teaching in the light of some variables. A M. A published thesis. International Islamic Sciences University, Amman.

Kostaris, C., Sergis, S., Sampson, D. G., Giannakos, M. N., \& Pelliccione, L. (2017). Investigating the Potential of the Flipped Classroom Model in K-12 ICT Teaching and Learning: An Action Research Study. Journal of Educational Technology \& Society, 20(1), 261-273.

Mahmoud, R. T. (2018). A strategy based on generative learning to develop creative writing skills and awareness of its processes among talented secondary school students. Journal of the Faculty of Education: Menoufia University. Faculty of Education, 33(2), 228-278.

Mahram, S. M. (2012). The effectiveness of an educational program based on the communicative approach in improving the functional and creative writing skills and linguistic intelligence of students. Unpublished Ph.D. Dissertation. Amman Arab University, Amman.

Musa, A. M. (2016). A proposed program in the Arabic language based on self-organized learning strategies to develop reading skills for academic study and writing and to raise academic self-efficacy among undergraduate students. Reading and Knowledge Magazine: Ain Shams University - Faculty of Education. Egyptian Association for Reading and Knowledge, 177, 49-113.

Nasr, M. M., Farraj, H. A., \& Suleiman, M. J. (2019). The effect of teaching based on NLP on developing creative writing skills in the preparatory stage: Reading and Knowledge Magazine: Ain Shams University Faculty of Education. Egyptian Association for Reading and Knowledge, 215, 109-127.

Niculescu, B.-O., \& Obilişteanu, G. (2016). Relational Aspects between ICT and the Modernization of Differentiated and Individualized Teaching of Foreign Languages in Higher Education. Buletin Stiintific, 21(1), 28-35. https://doi.org/10.1515/bsaft-2016-0033

Peiffer, H., Ellwart, T., \& Preckel, F. (2020). Ability self-concept and self-efficacy in higher education: An empirical differentiation based on their factorial structure. PLoS ONE, 15(7), 1-24. https://doi.org/10.1371/journal.pone.0234604

Qhouf, A. I. E.-S. (2018). A program based on brain-based learning to develop creative writing skills for linguistically superior students at the primary stage Educational Sciences: Cairo University. Faculty of Graduate Studies of Education, 4, 164-223.

Rakhmatullina, G. (2019). Information and Communication Technologies' Application in Foreign Language Teaching to Children of 4-6 Years (pp. 192-195). Proceedings of the Multidisciplinary Academic Conference.

Ramon-Casas, M., Nuño, N., Pons, F., \& Cunillera, T. (2019). The different impact of a structured peer-assessment task in relation to university undergraduates' initial writing skills. Assessment \& Evaluation in Higher Education, 44(5), 653-663. https://doi.org/10.1080/02602938.2018.1525337

Salem, A. M. (2006). A proposed strategy to activate the M-learning model in teaching/learning French as a foreign language in smart schools in light of the integration of information and communication technology and the knowledge economy. Studies in university education: Ain Shams University - Faculty of Education. University Education Development Center, 12, 198-283.

Saudi, A. H. (2017). A strategy based on generative learning to develop creative writing and self-regulation skills 
for secondary school students Studies in Curricula and Teaching Methods: Ain Shams University - Faculty of Education. Egyptian Association for Curriculum and Teaching Methods, 218, 91-127.

Temizkan, M. (2011). The Effect of Creative Writing Activities on the Story Writing Skill. Educational Sciences: Theory \& Practice, 11(2), 933-939.

Wai, M. (2012). An Investigation of the Environment and Teaching Practice of Information and Communication Technologies (ICT) in Pre-primary Education in Hong Kong. International Journal of Science in Society, 3(1), 101-116. https://doi.org/10.18848/1836-6236/CGP/v03i01/51313

Wang, C.-Y., Chang, C.-K., Lin, K.-J., \& Chen, G.-D. (2019). Effectiveness of web-based mechanism for teaching creative writing in the classroom. Innovations in Education \& Teaching International, 56(3), 282-294. https://doi.org/10.1080/14703297.2018.1464940

Zain, A.-D. G., \& Al-Jarrah, A.-M. A. (2016). Building a scale of creative writing skills for non-Arabic speaking students in Malaysia, An exploratory study. Journal of Linguistic and Literary Studies: International Islamic University, 7(3), 142-162.

\section{Copyrights}

Copyright for this article is retained by the author, with first publication rights granted to the journal.

This is an open-access article distributed under the terms and conditions of the Creative Commons Attribution license (http://creativecommons.org/licenses/by/4.0/). 